\title{
Syntheses of Model Substances for Polyacrylonitrile and Its Co-Polymers
}

\section{Some Properties of Model Substances}

By Toshihiro Takata, Hajime Ishii, Yoshiyuki Nishiyama

and Masakazu Taniyama

In the preceding paper, it has been reported that the dimer model of polyacrylonitrile $\mathrm{CH}_{3} \mathrm{CHCH}_{2} \mathrm{CHCH}_{3}$ (II) and the trimer model $\mathrm{CH}_{3} \mathrm{CHCH}_{2} \mathrm{CHCH}_{2} \mathrm{CHCH}_{8}$ (III) were liquid. But

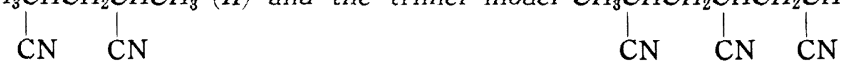

after storage for a long period, orystal appeared in them. The crystalline substance (II-2) were separated from the liquid substance (II-1) by separative crystallization and gas chromatography. From (III), three kind of crystalline substances, (III-1), (III-2) and (III-3), were obtained by the separative crystallization, which have definite melting points. In the preceding paper, it has been reported that the tetramer model, $\mathrm{CH}_{8} \mathrm{CHCH}_{2} \mathrm{CHCH}_{2} \mathrm{CHCH}_{2} \mathrm{CHCH}_{3}$ (IV), was waxy. How<smiles>N#CCCC(C#N)CC(C#N)CCC#N</smiles>

ever from (IV) also, by the separative crystallization the two crystalline substances, (IV-2), (IV-3), were obtained, which have higher melting points than others. The properties of these separated substances were discussed on their optical activity, infrared spectra, X-ray diffraction and on their carboxylic acid derivatives.

第 3 報 エステル，酸，アマイド共重合体模型の合成（その 1)

(1960 年 12 月 5 日受理)

高田利宏*・谷山雅 —*

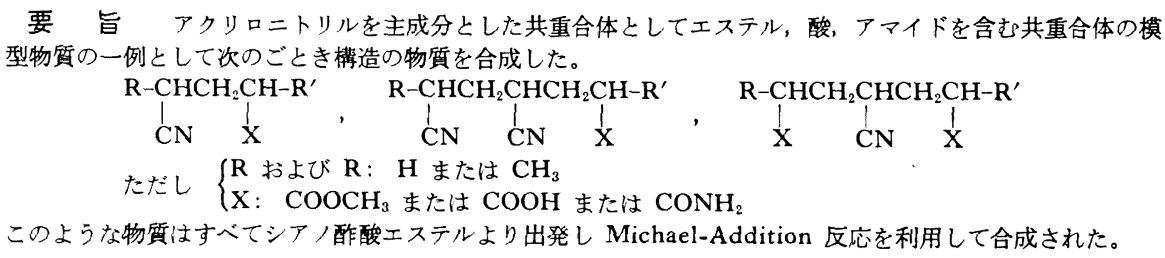

\section{1. 緒言}

前報1ににおいてはポリアクリロニトリルの模型物質と して脂肪族多価ニトリル誘導体（ニトリル基が炭素原子 1 個おきに結合した值鎖化合物）の合成を行なった。本 報においては，その二トリル基のうちのいずれかが $-\mathrm{COOH},-\mathrm{COOCH}_{3},-\mathrm{CONH}_{2}$ に置換された型の模型物 質の合成を試みた。いいかえればシアノカルボン酸ある いはシアノカルボン酸メチルェステルあるいはシアノカ ルボン酸アマイドの誘導体の合成である。このような誘 導体の合成について従来報告されているものにはジニト
リルの半加水分解によるもの 2 , 17)，あるいはラクトンと $\mathrm{KCN}$ との反応に基くもの年〜12),14),15)，18),19)，あるいは 八ロゲノカルボン酸エステルと $\mathrm{KCN}$ との反応に基くも $の^{8), 4)}$ ，マロン酸エステルより出発してMichael-Addition 反応を利用した方法5)，18) あるいはシア，酢酸エステル より出発した 誘導方法 ${ }^{(3)}{ }^{8)},{ }^{9}$ があり，その他副生成物と して得られたといら報告もある7),16)。

それらの中で, シアノ酢酸エステルより出発した方法 として大杉帛 は $\mathrm{CH}_{2}(\mathrm{CN}) \mathrm{CH}_{2} \mathrm{CH}_{2} \mathrm{COOC}_{2} \mathrm{H}_{5}$ を合成し， L. Ruzick ら ${ }^{8)}$ はシアノ酢酸エステルと $\mathrm{ClCH}_{2} \mathrm{CH}_{2} \mathrm{COOC}_{2} \mathrm{H}_{5}$

* Research Institute, Toho Rayon Co., Ltd. (Kitajima-cho, Itanogun, Tokushima) 


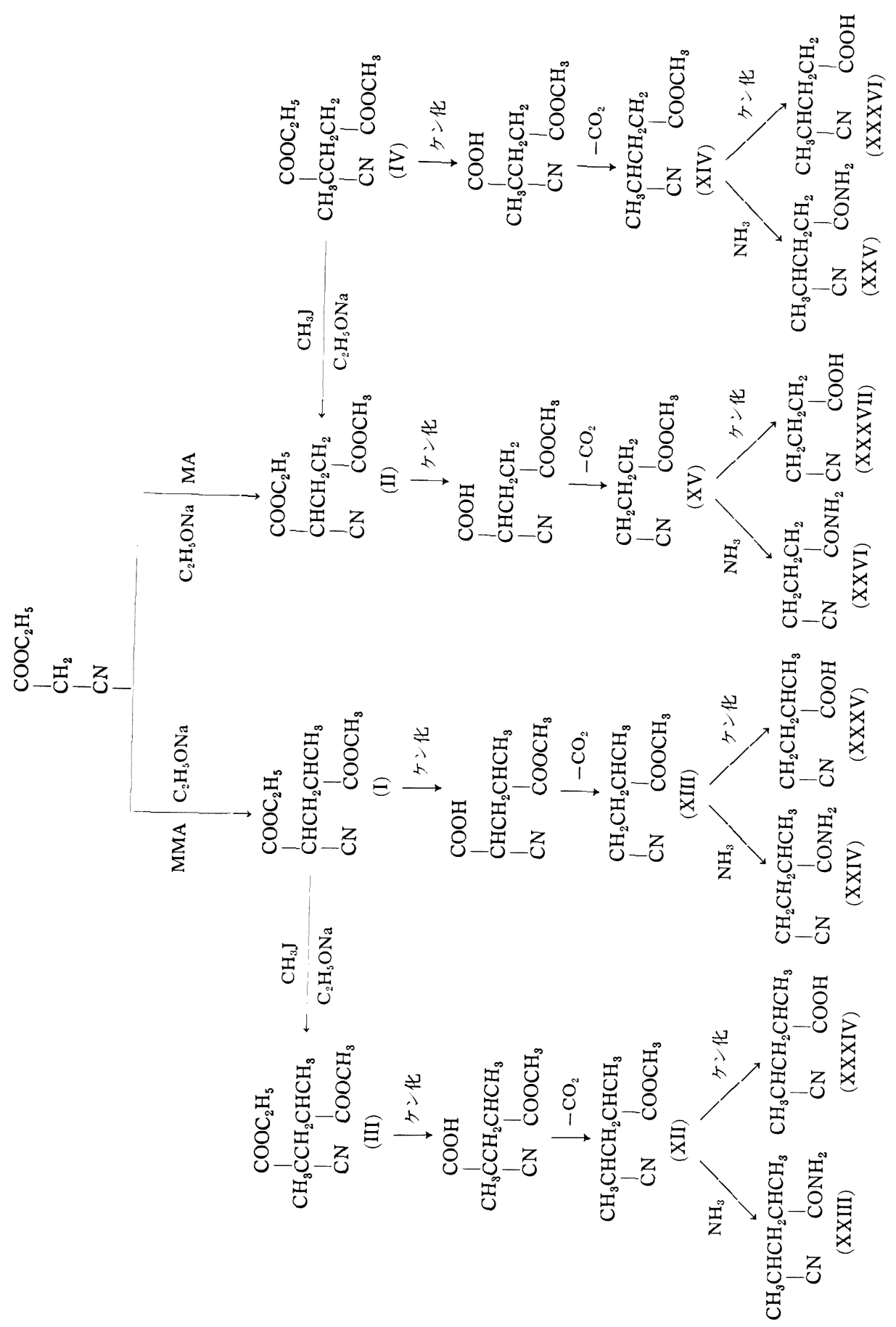




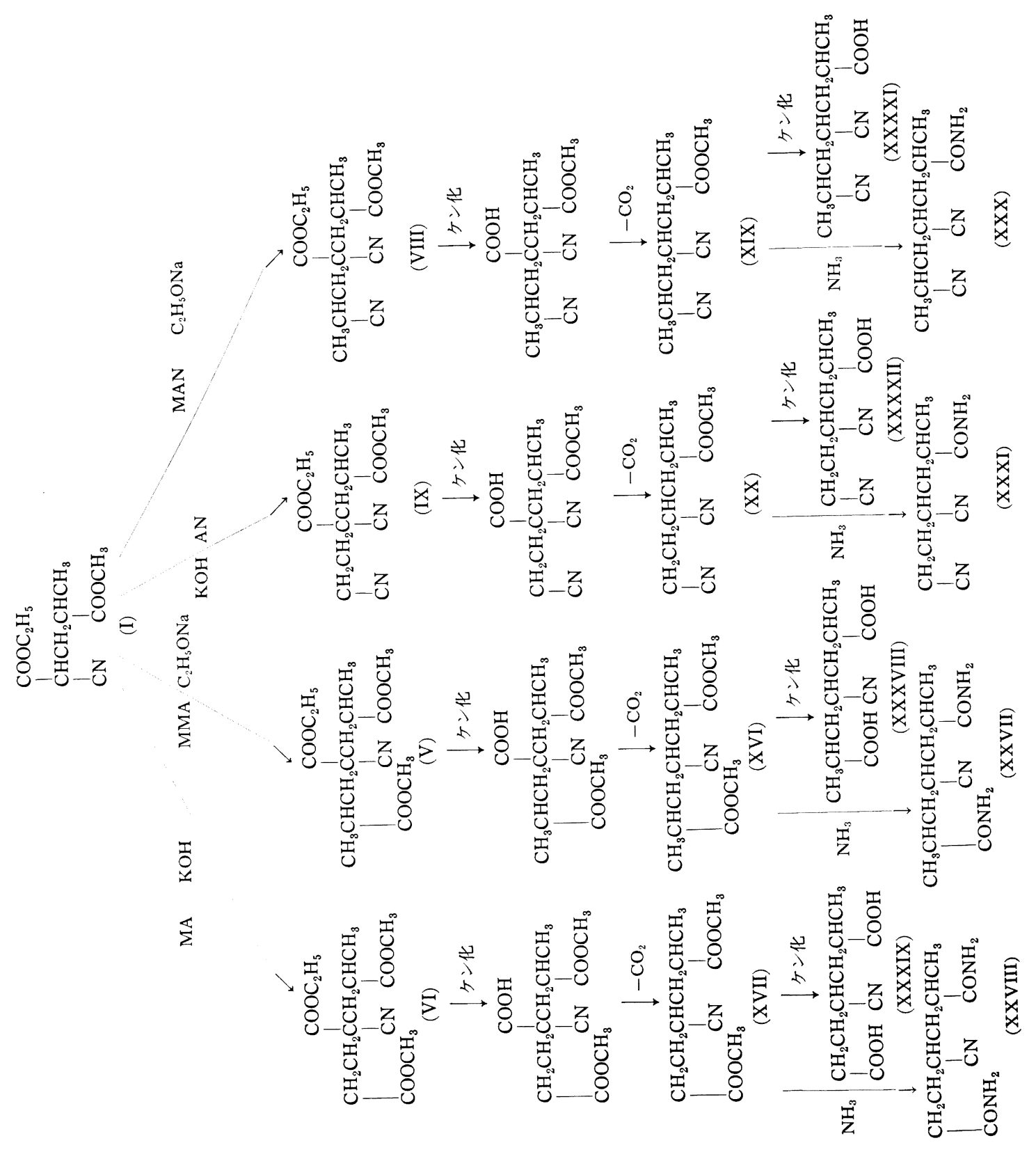




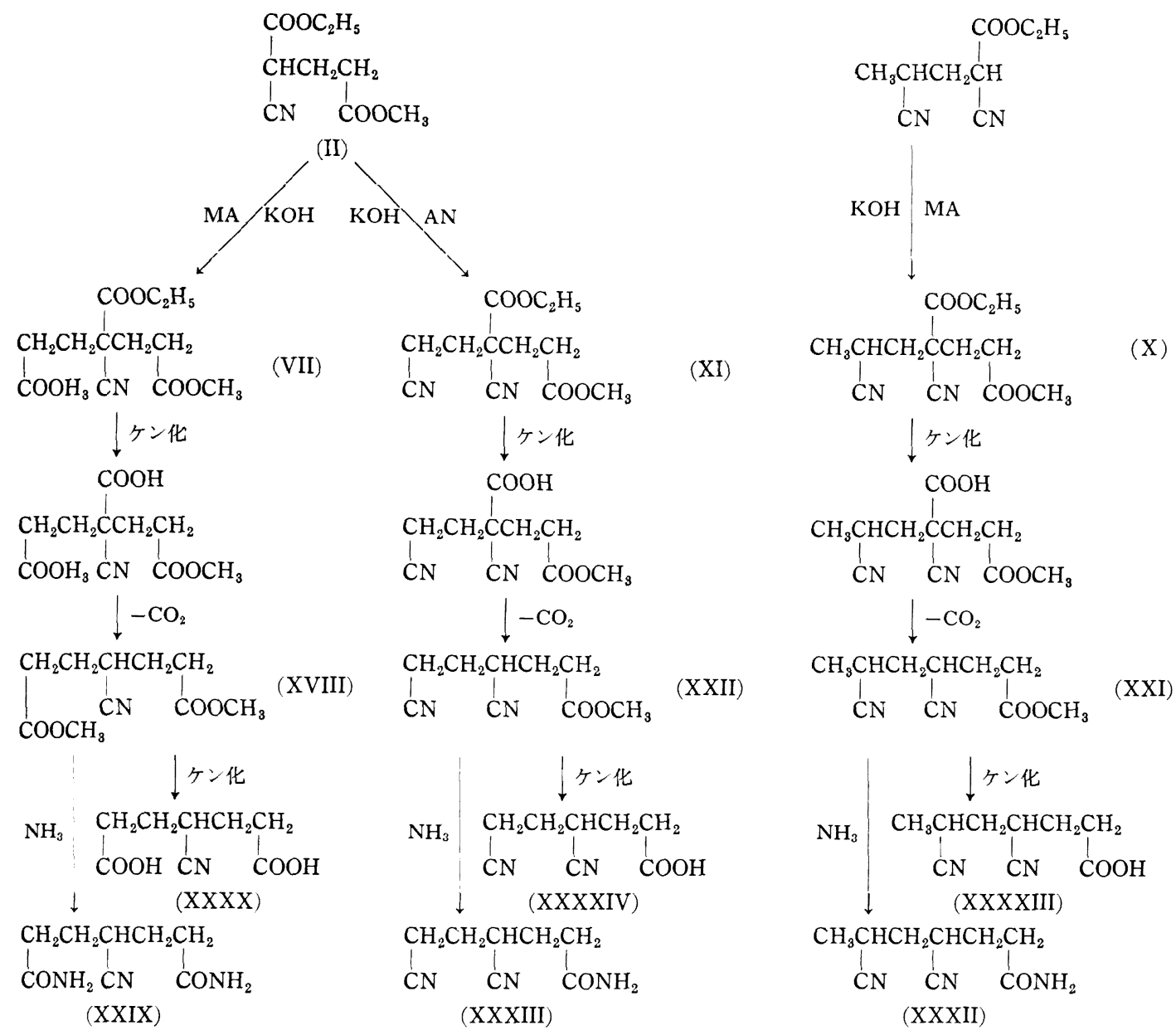

との反応を検討し, Zakharkin and Preobrazhenskii" $\mathrm{CH}_{2}\left(\mathrm{COOC}_{2} \mathrm{H}_{5}\right) \mathrm{CH}_{2} \mathrm{CH}(\mathrm{CN}) \mathrm{CH}_{2} \mathrm{CH}\left(\mathrm{COOCH}_{3}\right) \mathrm{CH}_{3}$ を合成 しているが，われわれもシアノ酶酸エステルより出発し て次に示す工程にてシアノカルボン酸誘尊体（アクリロ ニトリル共重合体模型物質）の合成を行ない，それぞれ 目的物を合成することができた。それらの目的物の中で (XII), (XIII), (XVI), (XVII), (XIX), (XX), (XXI), (XXII), (XXIII), (XXIV), (XXVII), (XXVIII), (XXX), (XXXI), (XXXII), (XXXIII), (XXXIV), (XXXV), (XXXVIII), (XXXXI), (XXXXII), (XXXXIII), (XXXXIV) はいずれも新物質と思われる。

(以下の文中でメチルアクリレートを MA，メチルメ タアクリレートを MMA，アクリロニトリルを AN, メ タアクリロニトリルを MAN と略記する。)

上記の合成物は, いずれも不省炭素を含んでるのでそ れぞれ立体異性体の存在が考えられるが，本報ではその
ことについて検討するには至らなかった。

\section{2. 実験の部}

2.1 シアノ酢酸エチルエステルへの MA， MMA, AN, MAN の付加

(II) の合成以外においては MA, AN の付加は $\mathrm{KOH}-$ メタノール溶液を触媒としてジオキサン溶液にて反応を 行ない, MMA, MAN の付加の場合には無水エタノー ル溶液中にて $\mathrm{NaOC}_{2} \mathrm{H}_{5}$ を触媒として使用した。

2.1.1 $\alpha$-シアノー $\gamma$-カルボメトキシーn-吉草酸エチル エステル $(\mathbf{I})$

MMAに対してシアノ酶酸エステルを過剩に使用して 反応させると(I) を得ることができたが，両者を同モル 量使用したときには (I) がほとんど得られずに (V) が多 量得られた。すなわち, Na $2.5 \mathrm{~g}$ を無水エタノール $65 \mathrm{cc}$ に溶解し，これをシア/酶酸エチルエステル $650 \mathrm{~g}(5.8$ 
Table 1 The properties of Michael-addition products

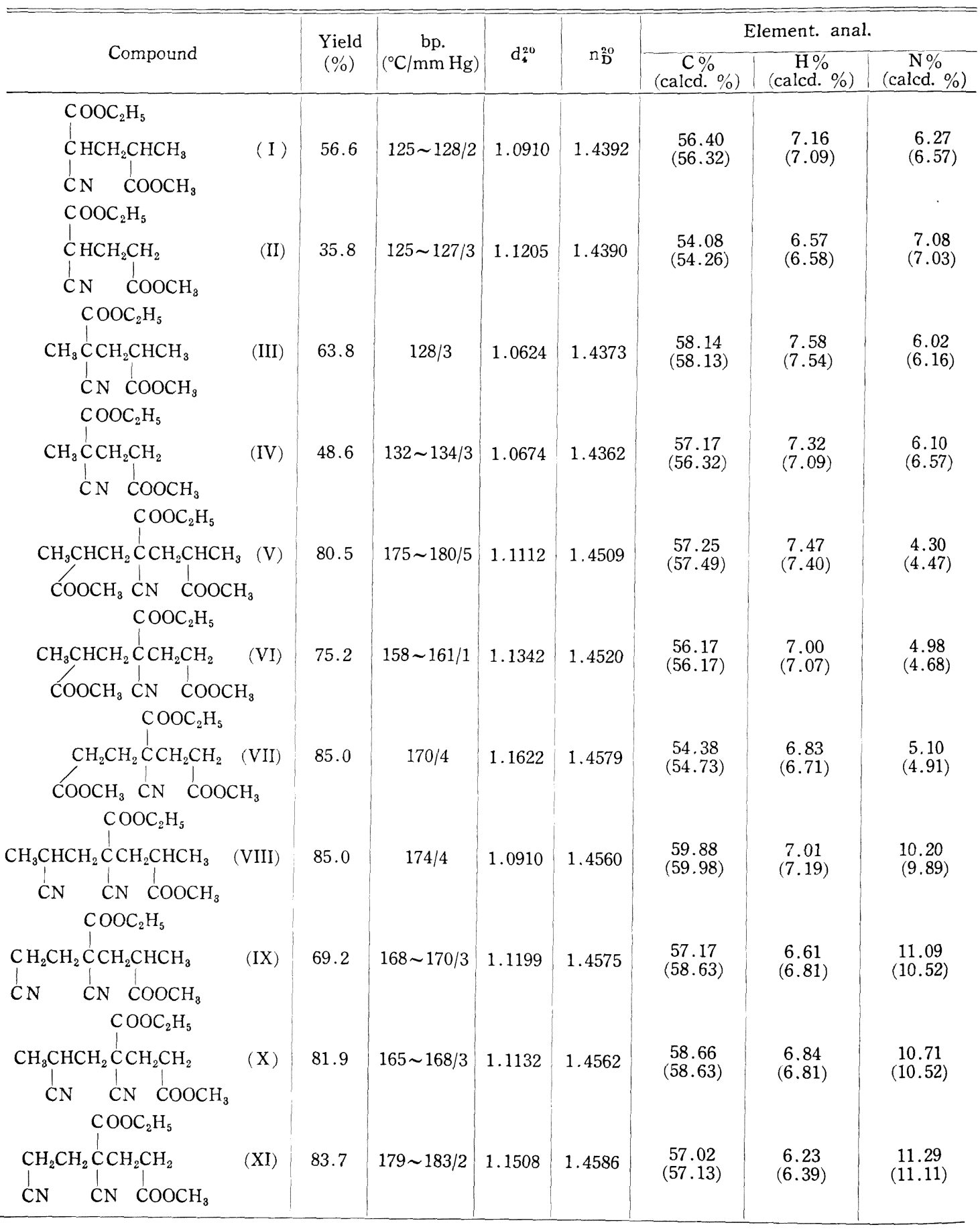


モル)に加え, 室温で $\frac{1}{2}$ 時間かきまぜた後加熱を開始し， $52^{\circ} \mathrm{C}$ に達してから MMA $120 \mathrm{~g}(1.2$ モル)を徐々に滴 加した。滴加所要時間 3 時間。滴加中に反応液温は $77^{\circ} \mathrm{C}$ に達した。滴加後更に $2 \frac{1}{2}$ 時間 $75^{\circ} \mathrm{C}$ にてかきまぜた後 1 夜放置し, 翌日塩酸にて反応液を中和し多量の水を加 えて油状層を分離し，その油状物から蒸留により Table 1 に示すよ5に (I) を得た。

\subsection{2 $\alpha$-シアノー $\gamma$-カルボメトキシ-n-酪酸 エチルエ} ステル (II)

Na $1.8 \mathrm{~g}$ (無水エタノール $50 \mathrm{cc}$ ), シアノ酶酸エチル エステル $335 \mathrm{~g}$ (約 3 モル), MA $70 \mathrm{~g}(0.82$ モル) を使用 して (I) の合成の場合とほぼ同様にして (II) を得た。結 果は Table 1 亿一括。

\subsection{3 $\alpha$-シアノ- $\alpha$-メチル- $\gamma$-カルボメトキシ-n-吉 草酸エチルエステル (III)}

Na $55 \mathrm{~g}$ を無水エタノール $1200 \mathrm{cc}$ に溶解し，これに (I) $511 \mathrm{~g}$ を加え室温にて $2 \frac{2}{3}$ 時間かきまぜた後ヨウ化メ チル $486 \mathrm{~g}$ を滴加した。滴加所要時間 2 時間, その間発 熱するのでときどき反応器を氷水で冷却して反応液温を $30 \sim 36^{\circ} \mathrm{C}$ に保持した。滴加終了後 3 時間継続してかき まぜた後, 1 夜放置し, 翌日エタノールを留去後水に投 入し, 分離してきた油状層を蒸留して (III) を得た。結 果は Table 1 亿一括。

\subsection{4 $\alpha$-シアノ- $\alpha$-メチル- $\gamma$-カルボメトキシーn-酪} 酸エチルエステル (IV)

(II) $50 \mathrm{~g}, \mathrm{Na} 5.75 \mathrm{~g}$ (無水エタノール $125 \mathrm{cc}$ ), ヨウ化 メチル $50 \mathrm{~g} よ り(\mathrm{III})$ の合成の場合と同様に処理して (IV) を得た。結果は Table 1 に一括。

\subsection{5 $\alpha \alpha^{\prime}$-ジメチル- $\gamma$-シアノー $\gamma$ ーカルボエトキシ・ピ メリン酸・ジメチルエステル(V)}

(I)に MMA を付加することにより簡単に合成できる がシアノ酢酸エチルエステルより直接合成した。すなお ち, シアノ酶酸エチルェステル $226 \mathrm{~g}(2$ モル) と MMA $400 \mathrm{~g}(4$ モル) と無水エタノール $200 \mathrm{cc}$ とを混合し, 液 温を $3 \sim 5^{\circ} \mathrm{C}$ に保ってかきまぜながら $\mathrm{Na} 4 \mathrm{~g}$ (無水エタ ノール $80 \mathrm{cc}$ に溶解) を徐々に滴加した。滴加所要時間 2 時間。滴加後, 反応液温を室温にまで上昇し室温で 7
時間かきまぜた後 1 夜放置した。翌日塩酸にて中和後水 に投じ, 油状層として分離し, 蒸留した。結果は Table 1 に一括。

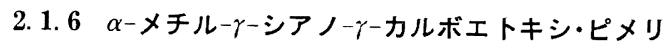
ン酸ジメルエステル (VI)

(I) $53 \mathrm{~g}$ をジオキサン $70 \mathrm{~g}$ と混合し,これに MA $20 \mathrm{~g}$ を加え, 外部を氷一食塩にて泠却してかきまぜながら濃 度 $30 \% \mathrm{KOH}$-メタノール溶液 $3 \mathrm{cc}$ を少量ずつ滴加し, 反応液温はその間 $30^{\circ} \mathrm{C}$ 以下に保たれた。滴加所要時間 30 分, 滴加後室温にて $2 \frac{3}{4}$ 時間かきまぜた後 1 夜放置 し, 翌日塩酸にて中和し, 水に投じて油状層を分離し, その油状層より(VI)を得た。結果は Table 1 亿一括。

\subsection{7 $\gamma$-シアノー} チルエステル (VII)

(II) に MA を付加することにより (VI) の場合と同様 にして (VII) が得られるはずであるが，シアノ酢酸エチ ルエステルと MA とから直接合成した。すなわち, シ アノ䣫酸エチルェステル $264 \mathrm{~g}, \mathrm{MA} 400 \mathrm{~g}$, ジオキサン $466 \mathrm{~g}, 30 \% \mathrm{KOH}$-メタノール溶液 $21 \mathrm{cc}$ を使用して (VI) の合成の場合上同様に反応した。結果は Table 1 に一括。

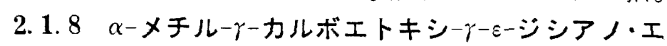
ナント酸メチルエステル (VIII)

(I) $724 \mathrm{~g}$ (3.4 モル) を MAN $235 \mathrm{~g}$ (3.4 モル) と混 合し,室温にてかきまぜながらこれに Na $4 \mathrm{~g}$ (無水エタ ノール $100 \mathrm{cc}$ に溶解）したものを 1 分間にて滴加し, 3 時間 $92 \sim 97^{\circ} \mathrm{C}$ にてかきまぜた後 1 夜放置し, 翌日塩酸 にて中和後水に投じて分離する油状層より (VIII) を得 た。結果は Table 1 に一括。

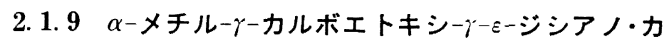
プロン酸メチルエステル (IX)

(I) $53 \mathrm{~g}, \mathrm{AN} 15 \mathrm{~g}$, ジオキサン $70 \mathrm{~g}$ の混液を(VI)の

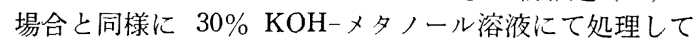
(IX)を得た。結果は Table 1 に一括。

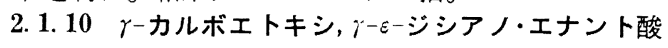
メチルエステル $(\mathbf{X})$

ジオキサン $280 \mathrm{~g}, \alpha$-メチルー $\alpha^{\prime}$-カルボエトキシ・グル タロニトリル $200 \mathrm{~g}, \mathrm{MA} 105 \mathrm{~g}, 30 \% \mathrm{KOH}$ メタノー

Table 2

\begin{tabular}{|c|c|c|c|c|c|c|}
\hline & bp. & $d_{\mathbf{4}}^{20}$ & $n_{\mathrm{D}}^{20}$ & $\begin{array}{c}\mathrm{C} \% \\
\text { (Calcd. \%) }\end{array}$ & $\begin{array}{c}\mathrm{H} \% \\
\text { (Calcd.\%) }\end{array}$ & $\begin{array}{c}\mathrm{N} \% \\
\text { (Calcd. \%) }\end{array}$ \\
\hline $\mathrm{CH}_{3} \mathrm{C}-\mathrm{CH}_{2}-\mathrm{CH}_{2}$ & $\begin{array}{c}111 \sim 112^{\circ} \mathrm{C} / \\
1 \mathrm{mmHg}\end{array}$ & 1.1229 & 1.4407 & $54.24(54.26)$ & $6.55(6.61)$ & $6.96(7.03)$ \\
\hline 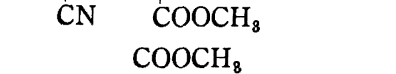 & & & & & & \\
\hline $\begin{array}{lll}\mathrm{CH}_{2}-\mathrm{CH}_{2}-\mathrm{C}-\mathrm{CH}_{2} \mathrm{CH}-\mathrm{CH}_{3}(\mathrm{IX})^{\prime} \\
\mid \mathrm{CN} & \mid & \mid \\
\mathrm{CN} & \mathrm{COOCH} & \end{array}$ & $\begin{array}{l}172^{\circ} \mathrm{C} / \\
1 \mathrm{mmHg}\end{array}$ & 1.1316 & 1.4570 & $57.07(57.15)$ & $6.55(6.40)$ & $11.38(11.11)$ \\
\hline
\end{tabular}


ル溶液 $10 \mathrm{cc}$ を使用し, (VI) の場合と同様にして $(\mathrm{X})$ を 得た。結果は Table 1 に一括。

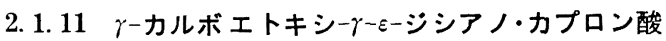
メチルェステル $(\mathbf{X I})$

(II) $200 \mathrm{~g}, \mathrm{AN} 60 \mathrm{~g}$ ，ジオキサン $280 \mathrm{cc}, 30 \% \mathrm{KOH}-$ メタノール溶液 $10 \mathrm{cc}$ を使用し (VI) の場合と同様に処 理して (XI) 合成した。結果は Table 1 に一括。

上記 Table 1 に見られるごとく, (IV) および (IX) は 元素分析值が計算值と一致するに至らなかったのである が十分次の工程に使用することができた。しかし一度ヶ ン化後ジアジメタンにて処理し Table 1 のごとくメチ ルエステルとして純粋物を得た。

2. 2
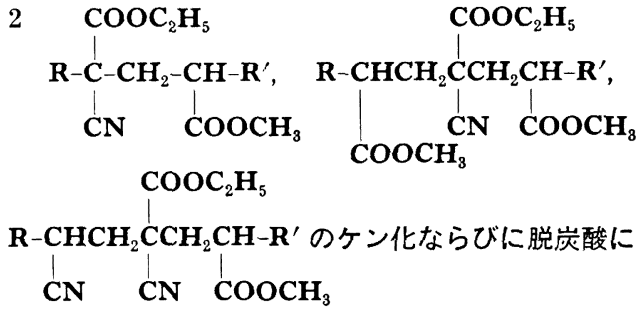

2. $2.1 \alpha$-メチルー $\gamma$-カルボメトキシーn-バレロニトリ ル (XII) ((III) のケン化)

(III) $300 \mathrm{~g}$ を泠却し $1 \sim 3^{\circ} \mathrm{C}$ に保ち，かきまぜながら

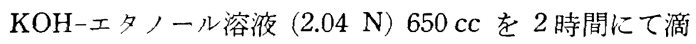
加した。そのときカリウム塩が析出し, これをロ過採取 後母液を 1 夜放置してから減圧濃縮した。濃縮後析出し た結晶をこし取り，先に得られたカリウム塩とあわせて 少量の水に溶解し, 塩酸酸性としてからェーテルで抽出 した。このエーテル溶液を重炭酸ソーダ水溶液とふりま ぜた後水溶液層を再び塩酸酸性之し, エーテルにて抽出 し, エーテル溶液からエーテルを留去しケン化生成物 $171 \mathrm{~g}$ を得た。

(脱炭酸ならびに精製)

この粘稠物 $171 \mathrm{~g}$ にピリジンをその 5 倍量, 銅粉をそ の $\frac{1}{2}$ 量加えて $105 \sim 110^{\circ} \mathrm{C}$ にて 45 分間かきまぜて脱炭 酸反応を完了し, 銅粉をロ去, ピリジンを減圧留去後エー テルに溶解し, 希塩酸, 重炭酸ソーダ水溶液, 水にて順 次洗浄後減圧蒸留に付して (XII) を得た。これでほとん ど純粋の状態にて得られるが,一度ケン化し，ジアジメ タンにて再ェステル化することにより精製した。(XII) の収率および性質は Table 2 に一括。

2. 2.2 r-カルボメトキシーn-バレロニトリル (XIII) (I) $107 \mathrm{~g}$ を無水エタノール $100 \mathrm{cc}$ に溶解し, $5 \sim 8^{\circ} \mathrm{C}$
にてかきまぜながら $\mathrm{KOH}$ (市販品) $33 \mathrm{~g}$, 無水エタノー ル $460 \mathrm{cc}$ の溶液を $1 \frac{2}{3}$ 時間にて滴加後, 室温にて 1 夜 放置し, 翌日エタノールを減圧留去後残留物を少量の水 に溶解し, 末ケン化物をエーテルにて抽出除去し, 水溶 液層を塩酸酸性としてからェーテルで抽出した。この エーテル溶液よりェーテルを留去しケン化生成物 $85 \mathrm{~g}$ を得た。(粘稠物質) これから (XII) の合成の場合と同 様に脱炭酸処理し (XIII) を得た。収率ならびに性状は Table 2 に一括。

2. $2.3 \alpha$-メチル- $\boldsymbol{\gamma}$-カルボメトキシーn-酪酸 (XIV)

(IV) $53 \mathrm{~g}$ を KOH-エタノール溶液 $(\mathrm{KOH} 16.5 \mathrm{~g}$, 無 水エ夕ノール $220 \mathrm{cc}$ ) にて (XIII) の場合と同様に処理し てケン化を行ない, 次いで脱炭酸して (XIV) を得た。収 率ならびにその性状は Table 2 に一括。

2. 2.4 r-カルボメトキシーn-ブチロニトリル $(\mathrm{XV})$

(II) $50 \mathrm{~g}$ を $\mathrm{KOH}-$ タノール溶液 ( $\mathrm{KOH} 16.5 \mathrm{~g}$, 無 水エタノール $170 \mathrm{cc}$ ) にて (XIII) の合成の場合と同様に 処理してヶン化し, 次いで脱炭酸して $(\mathrm{XV})$ を得た。収 率ならびにその性状は Table 2 に一括。

2. $2.5 \alpha, \alpha^{\prime}$-ジメチルー $\gamma$-シアノピメリン酸・ジメチル エステル $(\mathbf{X V I})$

(V) $458 \mathrm{~g}$ を $\mathrm{KOH}-$ エタノール溶液 $(\mathrm{KOH} 96 \mathrm{~g}$, $99.5 \%$ エタノール $1000 \mathrm{cc}$ ) にて (XIII) の場合と同様に 処理してケン化し, 次いで脱炭酸して $(\mathrm{XVI})$ を得た。収 率ならびにその性状は Table 2 に一括。

2. $2.6 \alpha$-メチルー $\gamma$ シアノ・ピメリン酸ジメチルエス テル $(\mathbf{X V I I})$

(VI) $240 \mathrm{~g}$ を $\mathrm{KOH}$-エタノール溶液(KOH $53 \mathrm{~g}, 99.5 \%$ エタノール $750 \mathrm{cc}$ ) にて (XIII) の場合と同様に処理し てケン化し, 次いで脱炭酸して (XVII) を得た。収率な らびにその性状は Table 2 に一括。

2. $2.7 \gamma$-シアノピメリン酸ジメチルエステル(XVIII)

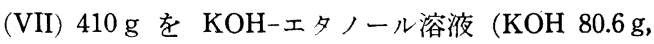
$99.5 \%$ エタノール $1000 \mathrm{cc}$ ) にて (XIII) の場合と同様に 処理してケン化し，次いで脱炭酸して（XVIII）を得た。 収率ならびにその性状は Table 2 に一括。

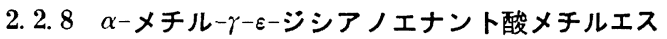
テル $(\mathbf{X I X})$

(VIII) $624 \mathrm{~g}$ を KOH-エタノール溶液 $(\mathrm{KOH} 190 \mathrm{~g}$, 無水エタノール $2200 \mathrm{cc}$ ) にて (XIII) の場合と同様に処 理してケン化し, 次いで脱炭酸して (XIX) を得た。収率 ならびに性状は Table 2 に一括。

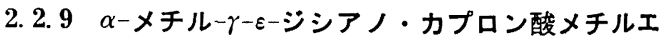
ステル $(\mathbf{X X})$

(IX) $220 \mathrm{~g}$ を $\mathrm{KOH}-$ タノール溶液 $(\mathrm{KOH} 54 \mathrm{~g}$, $99.5 \%$ エタノール $750 \mathrm{cc}$ ) にて (XIII) の場合と同様に 処理してケン化し, 次いで脱炭酸して $(\mathrm{XX})$ を得た。収 率ならびに性状は Table 2 に一括。 
Table 2 The properties of ester derivatives

\begin{tabular}{|c|c|c|c|c|c|c|c|}
\hline \multirow{2}{*}{ Compound } & \multirow{2}{*}{$\begin{array}{l}\text { Yield } \\
(\%)\end{array}$} & \multirow{2}{*}{$\begin{array}{c}\text { bp. } \\
\left({ }^{\circ} \mathrm{C} / \mathrm{mm} \mathrm{Hg}\right)\end{array}$} & \multirow{2}{*}{$\mathrm{d}_{4}^{20}$} & \multirow[b]{2}{*}{$\mathrm{n}$} & \multicolumn{3}{|c|}{ Element. anal. } \\
\hline & & & & & $\begin{array}{c}\mathrm{C} \% \\
\text { (calcd. \%) }\end{array}$ & $\begin{array}{c}\mathrm{H} \% \\
\text { (calcd. \%) }\end{array}$ & $\begin{array}{c}\mathrm{N} \% \\
\text { (calcd. \%) }\end{array}$ \\
\hline $\begin{array}{cll}\mathrm{CH}_{3} \mathrm{CHCH}_{2} \mathrm{CHCH}_{3} & \\
\mid \mathrm{CN} & \mathrm{COOCH}_{3} & \\
& & \text { (XII) }\end{array}$ & 41.7 & ${ }_{113 / 16}^{110}$ & 0.9858 & 1.4272 & $\begin{array}{c}61.73 \\
(61.91)\end{array}$ & $\begin{array}{c}8.44 \\
(8.44)\end{array}$ & $\begin{array}{c}9.25 \\
(9.03)\end{array}$ \\
\hline $\begin{array}{lll}\mathrm{CH}_{2} \mathrm{CH}_{2} \mathrm{CHCH}_{3} & \\
\mid & \mid & \\
\mathrm{CN} & \mathrm{COOCH}_{3} & \\
& & \text { (XIII) }\end{array}$ & 68.6 & $113 \sim$ & 1.0038 & 1.4280 & $\begin{array}{c}59.92 \\
(59.95)\end{array}$ & $\begin{array}{c}8.21 \\
(7.85)\end{array}$ & $\begin{array}{c}9.92 \\
(9.92)\end{array}$ \\
\hline $\begin{array}{lll}\mathrm{CH}_{3} \mathrm{CHCH}_{2} \mathrm{CH}_{2} & & \\
\vdots & \vdots & \\
\mathrm{CN} & \mathrm{COOCH}_{3} & \\
& & (\mathrm{XIV})\end{array}$ & 54.2 & $\stackrel{111 \sim}{113 / 16}$ & 1.0094 & 1.4252 & $\begin{array}{c}59.44 \\
(59.95)\end{array}$ & $\begin{array}{c}7.88 \\
(7.85)\end{array}$ & $\begin{array}{c}9.92 \\
(9.92)\end{array}$ \\
\hline $\begin{array}{l}\mathrm{CH}_{2} \mathrm{CH}_{2} \mathrm{CH}_{2} \\
\mathrm{CN} \quad \mathrm{COOCH}_{3} \quad(\mathrm{XV})\end{array}$ & 50.2 & ${ }_{112 / 16}^{110 \sim}$ & 1.0462 & 1.4268 & $\begin{array}{c}56.31 \\
(56.67)\end{array}$ & $\begin{array}{c}7.19 \\
(7.13)\end{array}$ & $\begin{array}{c}11.09 \\
(11.02)\end{array}$ \\
\hline$\underset{\mathrm{COOCH}_{3} \mathrm{CN}}{\mathrm{CH}_{3} \mathrm{CHCH}_{2} \mathrm{CHCH}_{2} \mathrm{CHCH}_{3}} \underset{(\mathrm{XVI})}{\mathrm{COOCH}_{3}}$ & 41.2 & ${ }_{132 / 2} \sim$ & 1.0607 & 1.4452 & $\begin{array}{c}59.78 \\
(59.73)\end{array}$ & $\begin{array}{c}8.05 \\
(7.94)\end{array}$ & $\begin{array}{c}5.87 \\
(5.81)\end{array}$ \\
\hline $\mathrm{COOCH}_{3} \mathrm{CN} \mathrm{COOCH}_{3} \mathrm{CH}_{2} \mathrm{CHCH}_{2} \mathrm{CHCH}_{3}$ & 37.9 & ${ }_{137 / 2}^{135}$ & 1.0846 & 1.4460 & $\begin{array}{c}57.98 \\
(57.88)\end{array}$ & $\begin{array}{c}7.65 \\
(7.95)\end{array}$ & $\begin{array}{c}6.07 \\
(6.14)\end{array}$ \\
\hline$\underset{\mathrm{COOCH}_{3} \mathrm{CN}}{\mathrm{CH}_{2} \mathrm{CH}_{2} \mathrm{CHCH}_{2} \mathrm{CH}_{2}} \mathrm{COOCH}_{(\mathrm{XVII})}$ & 52.8 & ${ }_{163 / 5}^{163 \sim}$ & 1.0980 & 1.4470 & $\begin{array}{c}56.59 \\
(56.32)\end{array}$ & $\begin{array}{c}7.09 \\
(7.09)\end{array}$ & $\begin{array}{c}6.70 \\
(6.57)\end{array}$ \\
\hline $\begin{array}{ccc}\mathrm{CH}_{3} \mathrm{CHCH}_{2} \mathrm{CHCH}_{2} \mathrm{CHCH}_{3} \\
\vdots \\
\mathrm{CN} & \mathrm{CN} & \underset{(\mathrm{XIX})}{\mathrm{COOCH}}\end{array}$ & 68.0 & $\begin{array}{l}137 \sim \\
139 / 2\end{array}$ & 1.0374 & 1.4490 & $\begin{array}{c}63.32 \\
(63.44)\end{array}$ & $\begin{array}{c}7.78 \\
(7.74)\end{array}$ & $\begin{array}{c}13.41 \\
(13.45)\end{array}$ \\
\hline 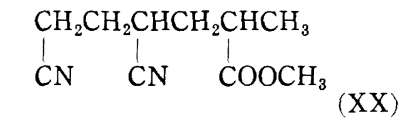 & 48.0 & $\underset{157 / 2}{155 \sim}$ & 1.0604 & 1.4530 & $\begin{array}{c}61.83 \\
(61.83)\end{array}$ & $\begin{array}{c}7.27 \\
(7.27)\end{array}$ & $\begin{array}{c}14.33 \\
(14.42)\end{array}$ \\
\hline $\begin{array}{ccc}\mathrm{CH}_{3} \mathrm{CHCH}_{2} \mathrm{CHCH}_{2} \mathrm{CH}_{2} \\
\mathrm{CN} & \mathrm{CN} & \underset{(\mathrm{XXI})}{\mathrm{COOCH}}\end{array}$ & 39.0 & ${ }_{154 / 2}^{152}$ & 1.0569 & 1.4519 & $\begin{array}{c}61.86 \\
(61.83)\end{array}$ & $\begin{array}{c}7.33 \\
(7.27)\end{array}$ & $\begin{array}{c}14.42 \\
(14.42)\end{array}$ \\
\hline 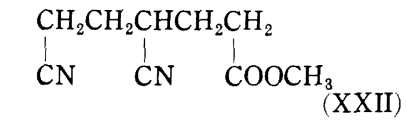 & 47.0 & ${ }_{162 / 2}^{160 \sim}$ & 1.0899 & 1.4550 & $\begin{array}{c}59.68 \\
(59.98)\end{array}$ & $\begin{array}{c}6.74 \\
(6.71)\end{array}$ & $\begin{array}{c}15.61 \\
(15.59)\end{array}$ \\
\hline
\end{tabular}

2. $2.10 \gamma-\varepsilon$-シシシアノ・エナント酸メチルエステル (XXI)

(X) $220 \mathrm{~g}$ を $\mathrm{KOH}$ ーエタノール溶液(KOH $54 \mathrm{~g}, 99.5 \%$ エタノール $750 \mathrm{cc}$ ) にて (XII) の場合と同様に処理して ケン化し, 次いで脱炭酸して $(\mathrm{XXI})$ を得た。収率ならび に性状は Table 2 に一括。

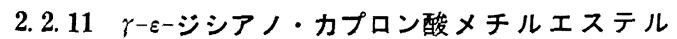
(XXII)

(XI) $200 \mathrm{~g}$ を $\mathrm{KOH}-$ タノール溶液(KOH $53 \mathrm{~g}, 99.5 \%$
エタノール $700 \mathrm{cc}$ ) にて (XIII) の場合と同様に処理し てヶン化し，次いで脱炭酸して（XXII）を得た。収率な らびに性状は Table 2 に一括。

\section{3 シアノカルボン酸エステルより シアノカルボン 酸アマイドの誘導}

上記 $(\mathrm{XII}) \sim(\mathrm{XXII})$ のシアノカルボン酸エステルと濃 厚アンモニア水(過剩量)とを混合し室温にて数日間かき まぜ誘導した。その反応条件ならびに結果は Table 3 に一括する。 
Table 3-1 Syntheses of the amide derivatives

\begin{tabular}{|c|c|c|c|c|c|c|}
\hline \multicolumn{3}{|c|}{ Reagents } & \multirow{2}{*}{$\begin{array}{l}\text { Reac. } \\
\text { period } \\
\text { (days) }\end{array}$} & \multirow[b]{2}{*}{ Derived amide compound } & \multicolumn{2}{|c|}{ Yield } \\
\hline $\begin{array}{l}\text { Ester de } \\
\text { (g) }\end{array}$ & eriv. & $\underset{(\mathrm{cc})}{13.8 \mathrm{~N}-\mathrm{NH}_{3}}$ aq. & & & (g) & $(\%)$ \\
\hline (XII) & 5.0 & 50 & 10 & $\underset{\mathrm{CN}}{\mathrm{CH}_{3} \mathrm{CHCH}_{2} \mathrm{CHCH}_{3}}$ & 3.8 & 81.5 \\
\hline (XIII) & 5.0 & 50 & 4 & $\begin{array}{ll}\mathrm{CH}_{2} \mathrm{CH}_{2} \mathrm{CHCH}_{3} \\
\mathrm{CN}_{\mathrm{N}}^{\mathrm{CONH}_{2}}\end{array} \quad$ (XXIV) & 4.4 & 98.5 \\
\hline (XIV) & 5.0 & 50 & 6 & $\begin{array}{ll}\mathrm{CH}_{3} \mathrm{CHCH}_{2} \mathrm{CH}_{2} \\
\stackrel{\mathrm{CN}}{\mid} \mathrm{CONH}_{2}\end{array}$ & 4.4 & 98.5 \\
\hline$(\mathrm{XV})$ & 1.9 & 5 & 5 & $\begin{array}{ll}\mathrm{CH}_{2} \mathrm{CH}_{2} \mathrm{CH}_{2} & \\
\mathrm{CN} & \mathrm{CONH}_{2}\end{array}$ & 0.3 & 17.9 \\
\hline$(\mathrm{XVI})$ & 10.0 & 50 & 11 & 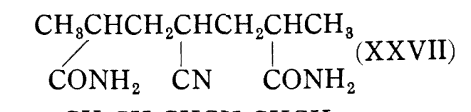 & 1.7 & 19.4 \\
\hline (XVII) & 8.8 & 26 & 4 & $\overbrace{\mathrm{CONH}_{2}}^{\mathrm{CH}_{2} \mathrm{CH}_{2} \mathrm{CHCH}_{2} \mathrm{CHCH}_{3}} \stackrel{\mathrm{CHNH}_{2}}{\mathrm{CONH}_{2}}(\mathrm{XXVIII})$ & 2.0 & 26.2 \\
\hline (XVIII) & 6.0 & 10 & 5 & 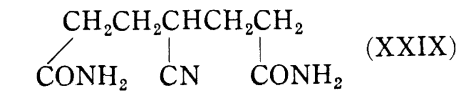 & 1.5 & 29.1 \\
\hline$(\mathrm{XIX})$ & 10.0 & 30 & 11 & $\begin{array}{rll}\mathrm{CH}_{3} \mathrm{CHCH}_{2} \mathrm{CHCH}_{2} \mathrm{CHCH}_{3} & \\
\mid \mathrm{CN} & \mathrm{CN} & \mathrm{CONH}_{2}\end{array}(\mathrm{XXX})$ & $\begin{array}{ll}\text { XXX-A } & 0 . \\
\text { XXX-B } & 0 . \\
\text { XXX-C } & 1\end{array}$ & $\left.\begin{array}{r}5.4 \\
8.6 \\
16.2\end{array}\right\} 30.2$ \\
\hline$(\mathrm{XX})$ & 8.0 & 13 & 5 & $\begin{array}{llll}\mathrm{CH}_{2} \mathrm{CH}_{2} \mathrm{CHCH}_{2} \mathrm{CHCH}_{3} & \\
\mid & \mathrm{CHCH} & \\
\mathrm{CN} & \mathrm{CN} & \mathrm{CONH}_{2} & \end{array}$ & 1.0 & 13.5 \\
\hline$(\mathrm{XXI})$ & 5.8 & 10 & 4 & $\begin{array}{cccc}\mathrm{CH}_{3} \mathrm{CHCH}_{2} \mathrm{CHCH}_{2} \mathrm{CH}_{2} & \\
\mid \mathrm{CN} & \mathrm{CN} & \mathrm{CONH}_{2} & \end{array} \quad(\mathrm{XXXII})$ & 0.8 & 15.0 \\
\hline (XXII) & 7.0 & 13 & 4 & $\begin{array}{llll}\underset{\mathrm{C}}{\mathrm{C}_{2}} \mathrm{CH}_{2} \mathrm{CHCH}_{2} \mathrm{CH}_{2} & \\
\mid & \mathrm{CH}^{2} & \mid & \\
\mathrm{CN} & \mathrm{CN} & \mathrm{CONH}_{2} & \end{array}$ & 0.7 & 10.9 \\
\hline
\end{tabular}

Table 3-2 The properties of the amide derivatives

\begin{tabular}{|c|c|c|c|c|c|}
\hline \multirow{2}{*}{$\begin{array}{l}\text { Amide } \\
\text { derivs. }\end{array}$} & \multirow{2}{*}{$\mathrm{mp}\left({ }^{\circ} \mathrm{C}\right)$} & \multirow{2}{*}{ Solvents for recrystallization } & \multicolumn{3}{|c|}{ Element. anal. } \\
\hline & & & $\mathrm{C} \%($ calcd. $\%)$ & $\mathrm{H} \%($ calcd. $\%)$ & N\% (calcd. \%) \\
\hline (XXIII) & $110 \sim 112$ & Methylethylketone (MEK) & $59.97 \quad(59.97)$ & $8.60(8.60)$ & $20.02(19.99)$ \\
\hline (XXIV) & $77 \sim 79$ & MEK + Benzene $(\mathrm{Bz})$ & $57.09(57.12)$ & $8.07(7.99)$ & $22.50(22.21)$ \\
\hline$(\mathrm{XXV})$ & $74 \sim 76$ & $\mathrm{MEK}+\mathrm{Bz}$ & $57.18(57.12)$ & $8.06(7.99)$ & $22.27(22.21)$ \\
\hline$(\mathrm{XXVI})$ & 74 & MEK & $52.85(53.55)$ & $7.14(7.19)$ & $24.52(24.99)$ \\
\hline (XXVII) & $250 *$ & MEK + Acetone $(\mathrm{Ac})+$ Water $(\mathrm{W})$ & $56.81(56.85)$ & $8.03(8.11)$ & $19.80(19.89)$ \\
\hline (XXVIII) & $178 \sim 180$ & $\mathrm{MEK}+\mathrm{Ac}+\mathrm{W}$ & $54.69(54.80)$ & $7.79(7.67)$ & $21.28(21.31)$ \\
\hline$(\mathrm{XXIX})$ & 141 & $\mathrm{MEK}+\mathrm{Ac}+\mathrm{W}$ & $52.44(52.44)$ & $7.15(7.15)$ & $22.98(22.94)$ \\
\hline$(\mathrm{XXX})-\mathrm{A}$ & $152 \sim 153$ & $\mathrm{MEK}+\mathrm{Bz}$ & $61.93(62.15)$ & $7.95(7.82)$ & $21.70(21.75)$ \\
\hline$(\mathrm{XXX})-\mathrm{B}$ & $128 \sim 131$ & $\mathrm{MEK}+\mathrm{Bz}$ & $61.97(62.15)$ & $8.13(7.82)$ & 21.85 \\
\hline$(\mathrm{XXX})-\mathrm{C}$ & $103 \sim 105$ & $\mathrm{MEK}+\mathrm{Bz}$ & $62.04(62.15)$ & $7.95(7.82)$ & 21.50 \\
\hline$(\mathrm{XXXI})$ & $98 \sim 100$ & MEK & $60.28(60.31)$ & $7.29(7.31)$ & $23.51(23.45)$ \\
\hline (XXXII) & $90 \sim 92$ & MEK & $59.93(60.31)$ & $7.40(7.31)$ & $23.48(23.45)$ \\
\hline (XXXIII) & $74 \sim 75$ & MEK & $57.86(58.16)$ & $6.72(6.71)$ & $25.36(25.44)$ \\
\hline
\end{tabular}

* (XXVII) melts sharply at $250^{\circ} \mathrm{C}$ when it is heated rapidly, but decomposes at $224 \sim 227^{\circ} \mathrm{C}$ when it is heated slowly. 


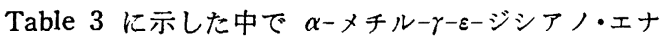
ントアマイド $(\mathrm{XXX})$ の場合には融点の異なる 3 種類の 結晶 ((XXX)-A, (XXX)-B, (XXX)-C) が得られたが 元素分析值はいずれも $(\mathrm{XXX})$ の計算值とよく一致して いるので立体異性体とも考えられる。

\section{4 シアノカルボン酸エステルよりシアノカルボン 酸の誘導}

上記シアノカルボン酸エステルを $\mathrm{KOH}-$ 無水エタノ ール溶液と混合し室温にて放置してケン化を行ない, 反 応液はその後減圧濃縮してからェーテルにて未ケン化物 を抽出除去し, 残ったケン化物を塩酸酸性としてからエ ーテルにて抽出し, エーテル溶液として遊離カルボン酸 を得る。これからェーテルを留去して目的物を得た。そ の結果は Table 4 に一括。

上記 Table 4 の中で (XXXVI), (XXXXIV) だけは 元素分析値とアルカリ滴定値より算出した分子量とがそ
れらの計算値と一致するには至らなかったが，他のもの は元素分析值に㧍いてもアルカリ滴定結果より算出した 分子量においても計算值とよく一致した。また，いずれ のカルボン酸誘導体も (XXXVIII) 以外は次の Table 5 に示すごとく結晶性 S-ベンジルチウロニウム塩を好収 率にて誘導した。

\section{3. 総 括}

以上のごとく中間体をも含めて 44 種類の物質の合成 を行なった。その中で (XXXVI) 抒よび (XXXXIV) だ けは少し不純物を含む状態でしか得られなかったが，両 者ともS-ベンジルチウロニウム誘導体としては純粋な 状態で確認することができたので本質的には合成できた ものと思われる。それ以外の 42 種類はすべて純粋な状 態で確認することができた。

付 記：本研究にあたりご助言を賜わった東邦レーヨン株

Table 4-1 The saponification of the ester derivatives

\begin{tabular}{|c|c|c|c|c|c|c|c|c|}
\hline \multirow{2}{*}{\multicolumn{2}{|c|}{$\begin{array}{l}\text { Ester } \\
\text { (g) }\end{array}$}} & \multirow{2}{*}{$\underset{(\mathrm{g})}{\mathrm{KOH}}$} & \multirow{2}{*}{$\begin{array}{l}\text { Ethanol } \\
\text { (g) }\end{array}$} & \multirow{2}{*}{$\begin{array}{l}\text { Reac. } \\
\text { period } \\
\text { (days) }\end{array}$} & \multirow{2}{*}{\multicolumn{2}{|c|}{ Derived carboxylic acid compds. }} & \multicolumn{2}{|c|}{ Yield } \\
\hline & & & & & & & (g) & $(\%)$ \\
\hline (XII) & 5.0 & 2.1 & 28 & 1 & $\begin{array}{cc}\mathrm{CH}_{3} \mathrm{CHCH}_{2} \mathrm{CHCH}_{3} \\
\mid \\
\mathrm{CN} & \mathrm{COOH}\end{array}$ & (XXXIV) & 0.9 & 20.0 \\
\hline (XIII) & 5.6 & 2.6 & 40 & 3 & $\begin{array}{l}\mathrm{CH}_{2} \mathrm{CH}_{2} \mathrm{CHCH}_{3} \\
\mathrm{CN} \quad \mathrm{COOH}\end{array}$ & $(\mathrm{XXXV})$ & 0.7 & 14.0 \\
\hline (XIV) & 5.6 & 2.6 & 40 & 3 & 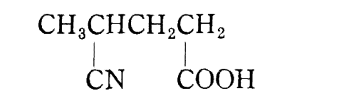 & $(\mathrm{XXXVI})$ & 0.7 & 14.0 \\
\hline (XV) & 1.9 & 1.0 & 14 & 2 & $\begin{array}{l}\mathrm{CH}_{2} \mathrm{CH}_{2} \mathrm{CH}_{2} \\
\vdots \mathrm{CN} \quad \mathrm{COOH}\end{array}$ & (XXXVII) & 0.7 & 41.2 \\
\hline$(\mathrm{XVI})$ & 10.0 & 5.5 & 50 & 2 & $\begin{array}{c}\mathrm{CH}_{3} \mathrm{CHCH}_{2} \mathrm{CHCH}_{2} \mathrm{CHCH}_{3} \\
\mathrm{COOH} \quad \mathrm{CN} \\
\mathrm{COOH}\end{array}$ & $(\mathrm{XXXVIII})$ & 7.2 & 81.5 \\
\hline (XVII) & 5.0 & 9.0 & 120 & 4 & 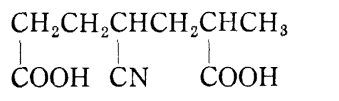 & $(\mathrm{XXXIX)}$ & 1.8 & 40.9 \\
\hline (XVIII) & 4.3 & 2.6 & 35 & 2 & $\begin{array}{l}\mathrm{CH}_{2} \mathrm{CH}_{2} \mathrm{CHCH}_{2} \mathrm{CH}_{2} \\
\mid \\
\mathrm{COOH} \mathrm{CN} \\
\mathrm{COOH}\end{array}$ & $(\mathrm{XXXX})$ & 2.1 & 56.8 \\
\hline$(\mathrm{XIX})$ & 9.0 & 2.5 & 50 & 2 & $\begin{array}{ccc}\mathrm{CH}_{3} \mathrm{CHCH}_{2} \mathrm{CHCH}_{2} \mathrm{CHCH}_{3} \\
\mid \mathrm{CN} & \mathrm{CN} & \mathrm{COOH}\end{array}$ & $(\mathrm{XXXXI})$ & 6.4 & 76.2 \\
\hline$(\mathrm{XX})$ & 5.8 & 2.1 & 25 & 3 & $\begin{array}{lll}\mathrm{CH}_{2} \mathrm{CH}_{2} \mathrm{CHCH}_{2} \mathrm{CHCH}_{3} \\
\mid \\
\mathrm{CN} & \mathrm{CN} & \mathrm{COOH}\end{array}$ & $(\mathrm{XXXXII})$ & 0.8 & 14.8 \\
\hline$(\mathrm{XXI})$ & 3.0 & 1.0 & 14 & 3 & $\begin{array}{ccc}\mathrm{CH}_{3} \mathrm{CHCH}_{2} \mathrm{CHCH}_{2} \mathrm{CH}_{2} \\
\vdots \\
\mathrm{CN} & \mathrm{CN} & \mathrm{COOH}\end{array}$ & (XXXXIII) & 1.3 & 46.6 \\
\hline (XXII) & 5.0 & 1.9 & 27 & 2 & 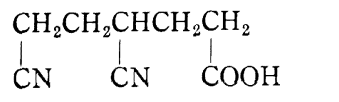 & $(\mathrm{XXXXIV})$ & 1.0 & 21.7 \\
\hline
\end{tabular}


Table 4-2 The properties of the carboxylic acid compounds

\begin{tabular}{|c|c|c|c|c|c|c|}
\hline \multirow[b]{2}{*}{ Compound } & \multirow[b]{2}{*}{ mp. d. $n_{\mathrm{D}}$ etc. } & \multirow{2}{*}{$\begin{array}{l}\text { Distilled temp. } \\
\text { (with micro flask) }\end{array}$} & \multirow{2}{*}{$\begin{array}{l}\text { Mol. Wt. } \\
\text { from the } \\
\text { titration } \\
\text { with NaOH } \\
\text { (Calcd. } \\
\text { Mol. Wt.) }\end{array}$} & \multicolumn{3}{|c|}{ Element. anal. } \\
\hline & & & & $\begin{array}{c}\mathrm{C} \% \\
(\text { calcd. \%) }\end{array}$ & $\begin{array}{c}\mathrm{H} \% \\
\text { (calcd. \%) }\end{array}$ & $\begin{array}{c}\mathrm{N} \% \\
\text { (calcd. \%) }\end{array}$ \\
\hline$(\mathrm{XXXIV})$ & $d_{4}^{26.5} \quad 1.0356, \quad n_{\mathrm{D}}^{26.5} 1.4339$ & $128-130^{\circ} \mathrm{C} / 1 \mathrm{mmHg}$ & $\begin{array}{c}141.0 \\
(141.2)\end{array}$ & $\begin{array}{c}58.72 \\
(59.55)\end{array}$ & $\begin{array}{c}7.79 \\
(7.86)\end{array}$ & $\begin{array}{l}10.09 \\
(9.92)\end{array}$ \\
\hline$(\mathrm{XXXV})$ & $d_{4}^{26} \quad 1.0676, n_{\mathrm{D}}^{26} \quad 1.4325$ & $127-130^{\circ} \mathrm{C} / 1 \mathrm{mmHg}$ & $\begin{array}{c}134.5 \\
(127.1)\end{array}$ & $\begin{array}{c}56.55 \\
(56.68)\end{array}$ & $\begin{array}{c}7.16 \\
(7.13)\end{array}$ & $\begin{array}{c}11.04 \\
(11.02)\end{array}$ \\
\hline$(\mathrm{XXXVI})$ & mp. $31^{\circ} \mathrm{C}$ & $127-130^{\circ} \mathrm{C} / 1 \mathrm{mmHg}$ & $\begin{array}{c}143.0 \\
(127.1)\end{array}$ & $\begin{array}{c}56.62 \\
(56.68)\end{array}$ & $\begin{array}{c}7.43 \\
(7.13)\end{array}$ & $\begin{array}{c}10.97 \\
(11.02)\end{array}$ \\
\hline (XXXVII) & mp. $37^{\circ} \mathrm{C}$ & $145^{\circ} \mathrm{C} / 1 \mathrm{mmHg}$ & $\begin{array}{c}113.2 \\
(113.1)\end{array}$ & $\begin{array}{c}52.99 \\
(53.09)\end{array}$ & $\begin{array}{c}6.20 \\
(6.24)\end{array}$ & $\begin{array}{c}12.10 \\
(12.39)\end{array}$ \\
\hline (XXXVIII) & mp. $142-143^{\circ} \mathrm{C}$ & $193^{\circ} \mathrm{C} / 3 \times 10^{-4} \mathrm{mmHg}$ & $\begin{array}{c}210.2 \\
(213.2)\end{array}$ & $\begin{array}{c}56.00 \\
(56.32)\end{array}$ & $\begin{array}{l}7.13 \\
(7.09)\end{array}$ & $\begin{array}{c}6.57 \\
(6.57)\end{array}$ \\
\hline$(\mathrm{XXXIX})$ & paste-like sticky & $180-190^{\circ} \mathrm{C} / 3 \times 10^{-4} \mathrm{mmHg}$ & $\begin{array}{c}201.4 \\
(199.2)\end{array}$ & $\begin{array}{c}54.42 \\
(54.26)\end{array}$ & $\begin{array}{c}6.83 \\
(6.58)\end{array}$ & $\begin{array}{l}7.18 \\
(7.03)\end{array}$ \\
\hline$(\mathrm{XXXX})$ & mp. $93-94^{\circ} \mathrm{C}$ & $180-195^{\circ} \mathrm{C} / 3 \times 10^{-4} \mathrm{mmHg}$ & $\begin{array}{c}187.7 \\
(185.2)\end{array}$ & $\begin{array}{c}55.72 \\
(55.68)\end{array}$ & $\begin{array}{c}6.08 \\
(6.04)\end{array}$ & $\begin{array}{c}13.23 \\
(13.53)\end{array}$ \\
\hline$(\mathrm{XXXXI})$ & paste-like sticky & $165^{\circ} \mathrm{C} / 3 \times 10^{-4} \mathrm{mmHg}$ & $\begin{array}{c}193.9 \\
(194.2)\end{array}$ & $\begin{array}{c}61.22 \\
(61.83)\end{array}$ & $\begin{array}{c}7.24 \\
(7.26)\end{array}$ & $\begin{array}{c}14.54 \\
(14.43)\end{array}$ \\
\hline (XXXXII) & mp. $96-98^{\circ} \mathrm{C}$ & $163^{\circ} \mathrm{C} / 3 \times 10^{-4} \mathrm{mmHg}$ & $\begin{array}{c}179.4 \\
(180.2)\end{array}$ & $\begin{array}{c}59.44 \\
(59.98)\end{array}$ & $\begin{array}{l}6.70 \\
(6.71)\end{array}$ & $\begin{array}{l}15.63 \\
(15.55)\end{array}$ \\
\hline (XXXXIII) & paste-like sticky & $185^{\circ} \mathrm{C} / 3 \times 10^{-4} \mathrm{mmHg}$ & $\begin{array}{c}185.8 \\
(180.2)\end{array}$ & $\begin{array}{c}59.61 \\
(59.98)\end{array}$ & $\begin{array}{c}6.88 \\
(6.71)\end{array}$ & $\begin{array}{c}15.78 \\
(15.55)\end{array}$ \\
\hline (XXXXIV) & paste-like sticky & $175^{\circ} \mathrm{C} / 3 \times 10^{-4} \mathrm{mmHg}$ & $\begin{array}{c}180.0 \\
(166.2)\end{array}$ & $\begin{array}{c}56.93 \\
(57.82)\end{array}$ & $\begin{array}{c}6.26 \\
(6.06)\end{array}$ & $\begin{array}{c}16.40 \\
(16.86)\end{array}$ \\
\hline
\end{tabular}

Note: In this Table the properties of (XXXIV)-(XXXVII) represent that of the materials which are distilled with micro flask. From this results it can be said that no reactions like imide-ring-formation ${ }^{18)}$ have occured during distillation. But about (XXXVIII)-(XXXXIV), it is described on undistilled substances. These compounds can be distilled at the temperature above mentioned, but from the results of the elementary analysis and the titration with $\mathrm{NaOH}$ it is detected that the reaction like imide-ring-formation or acidanhydride-ring-formation ${ }^{20}$ have been occured during distillation. So, it is not described here about distilled materials of (XXXVIII)(XXXXIV).

Table 5 S-Benzylthuronium salts of cyano carboxylic acids

(Recrystallized from water)

\begin{tabular}{l|c|c|c|c}
\hline \multirow{2}{*}{$\begin{array}{c}\text { Used original } \\
\text { acids }\end{array}$} & mp. of salts $\left({ }^{\circ} \mathrm{C}\right)$ & \multicolumn{3}{|c}{ Element. anal. } \\
\cline { 3 - 5 } & & $\mathrm{C} \%$ (calcd. \%) & $\mathrm{H} \%$ (calcd. \%) & $\mathrm{N} \%$ (calcd. \%) \\
\hline (XXXIV) & $137-138$ & $58.80(58.60)$ & $7.10(6.89)$ & $13.78(13.67)$ \\
(XXXV) & $118-120$ & $57.31(57.31)$ & $6.62(6.53)$ & $14.14(14.32)$ \\
$($ XXXVI) & $143-145$ & $57.36(57.31)$ & $6.67(6.53)$ & $14.35(14.32)$ \\
(XXXVII) & $137-138$ & $55.58(55.89)$ & $6.03(6.13)$ & $14.75(15.04)$ \\
(XXXVIII) & paste-like, sticky & - & & - \\
(XXXIX) & $151-153$ & $56.57(56.47)$ & $6.23(6.26)$ & $13.25(13.25)$ \\
(XXXX) & $164-166$ & $55.72(55.68)$ & $6.08(6.04)$ & $13.23(13.53)$ \\
(XXXXI) & $122-124$ & $59.52(59.97)$ & $6.72(6.71)$ & $15.05(15.54)$ \\
(XXXXII) & $127-128$ & $5848(58.93)$ & $6.37(6.40)$ & $16.18(16.17)$ \\
(XXXXIII) & $133-135$ & $59.04(58.93)$ & $6.38(6.40)$ & $16.25(16.17)$ \\
(XXXXIV) & $142-143$ & $58.25(57.81)$ & $6.11(6.06)$ & $16.92(16.85)$ \\
\hline
\end{tabular}


式会社研究所川勝道比古所長ならびに徳島大学薬学部名誉教授 吉岡寅吉博士に深謝し, 実験に協力せられた広井膂, 西条博の 両氏, 元素分析を実施された井上敏一, 矢野桂子の両氏に謝意 を表する。なお，昭和 35 年 10 月 7 日 日本化学会中国四国 支部第 31 回常会にて講演したものである。

\section{文献}

1) 高田利芸, 谷山雅一：高化, 16, 693(1959)

2) S. M. McElvain and R. D. Mullineaux : J. Am. Chem. Soc., 74, 1811 1816(1952)

3) E. C. Lodd and H. Sargent : USP 2655521 (1953)

4) M. Rothstein: J. Am. Chem. Soc., 76, 3038 (1954)

5) J. O. Jilek and V. Michajlszyn : Chem. Abst., 49, 9507 (1955)

6) 大杉邦三：薬誌，77，333(1957)

7) N. F. Albertson: J. Am. Chem. Soc., 72, 2594 (1950)

8) L. Ruzick, et al. : Helv. Chim. Acta, 17, 183(1934)

9) L. I. Zakharkin and N. A. Preobrazhenskii :
Chem. Abst., 48, $3367(1954)$; Zhur. Obshchei Khim., 23, 518 522(1953)

10) H. Hausmann and R. Bäumler: Ger. P 707853 (1941)

11) W. Reppe, et al. : Ann., 596, 1 5(1955)

12) G. Paris, et al. : Can. J. Chem., 33, 1724(1955)

13) J. A. Rumpf : Helv. Chim. Acta, 35, 2116(1952)

14) W. Wislicenus: Ann., 233, $113(1886)$

15) C. Bordenca and H. G. Sellers Jr. : USP 2736740 (1956)

16) C. G. Overberger, et al. : J. Am. Chem. Soc., 75, 2082 (1953)

17) Inventa A.-G. : $B P 78258(1957)$

18) W. Reppe, et al. : Ann., 596, 158 224 (1955)

19) Henry: Bull. Acad. Royale de Belgique [3] 18, 176 (Beilstein II. 634)

20) H. Zahn and P. Schäfer: Chem. Ber., 92, 736 (1959)

\section{Syntheses of Model Substances for Polyacrylonitrile and Its Co-Polymers}

\section{Syntheses of Model Substances of Co-Polymers Including Ester-, Carboxyl- or Amide-Group}

By Toshihiro Takata and Masakazu Taniyama

As model substances for co-polymers of acrylonitrile and some co-monomer units which included methyl ester, carboxylic or amide group, three types of substances were prepared from cyano acetic acid ester using Michael reaction as follow :

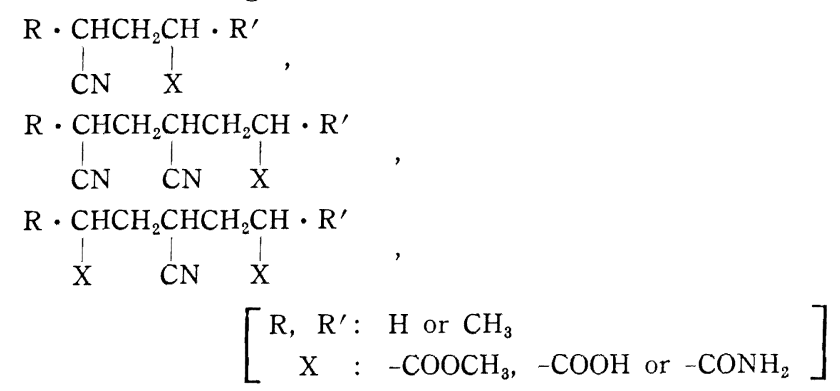

\footnotetext{
* Research Institute, Toho Rayon Co., Ltd. (Kitajima-cho, Itano-gun, Tokushima)
} 